\title{
ASCARIS LUMBRICOIDES: REINFECTION IN CHILDREN BEARING AN ESTABLISHED WORM BURDEN
}

\author{
Fausto E. Lima Pereira, Andrea P. Sampaio, \\ Carlos Musso and Jane S. Castelo.
}

\begin{abstract}
To clarify the existance of reinfection in children bearing an established Ascaris lumbricoides infection, the authors evaluated the weight and the length of worms collected from ten cases of ascaridiasis. The worm burden was greater than 27 worms in nine cases. In seven cases the weight and the length of worms showed little variation, with unimodal distribution of values, suggesting that all the worms in each case belong to the same population, originated from a single brood infection or from successive infections over small time intervals. In three cases there was great variation in worm size indicated by the different values for the means and medians and by the high values for the standard deviation and coefficient of variation. In these three cases there was a bimodal distribution of worm's size suggesting the coexistance of two distinct populations: one, less numerous, composed of mature worms and the other, more numerous, composed of immature worms, in two cases, and two distinct populations of immature worms in one case. The existance of worms in different stages of maturation indicates that the less mature population was acquired when the mature worms were established in the gut. These results indicate that the reinfection with Ascaris in children bearing an established infection is not rare and resistance induced by a preexisting infection is not the rule.
\end{abstract}

Key-words: Ascaris lumbricoides. Ascariasis.

Previous reports evaluating the size of Ascaris lumbricoides worms expelied after treatment or collected at autopsy have demonstrated that the size distribution (weight and length) is unimodal in each patient ${ }^{26}$. This observation suggested the predominance of a single brood infection or successive infections over small time intervals in human ascariasis. It has been hypothesized that successful development of Ascaris within the host occurs only in the absence of an established infection in the small intestine. The protective effect of an extant worm population against subsequent invaders has been confirmed in experimental infection with Ascaridia galli in chickens $s^{4}$ and acquired resistance against Ascaris larvae has been demonstrated in experimental infections in mices. Studies of chemotherapeutic elimination of established human Ascaris lumbricolides infection in endemic areas

\footnotetext{
Departamento de Patologia do Centro Biomédico, Universidade Federal do Espírito Santo e Serviço de Patologia do Hospital Infantil Nossa Senhora da Glória, Vitória, ES.

Endereço para correspondência: Dr. Fausto E. Lima Pereira. Dept $^{\circ}$ de Patologia/CBM/UFES. Caixa Postal 780, 29000 Vitória ES.

Recebido para publicação em 02/08/91.
}

have shown that the clearance of worms is followed rapidly by reinfection, indicating a loss of reistance against reinfection after elimination of a pre-existing worm burden ${ }^{3}$.

Recently Baird et al $^{1}$ reported a fatal Ascaris infection in a child with a massive worm burden composed of two populations: a small number of heavy worms (male and female) and a large number of lighter worms (male and female). The authors suggested that the heavier worms represented an older pre-existing population, while the smaller, more numerous worms with umimodal size distribution, represented a younger population acquired as a single brood infection. According to the authors, this was the first report of superimposed Ascaris reinfection in man.

To clarify the existance of reinfection in children bearing an established Ascaris lumbricoides infection, we studied the weight and length of worms colected at autopsy (nine cases) or after surgery (one case) from children with Ascaris infection. The worm burden was greater than 27 worms in nine of ten cases. Two distinct populations were observed in three cases, indicating that reinfection with Ascaris 
Pereira FEL, Sampaio AP, Musso C, Castelo JS. Ascaris lumbricoides: reinfection in children bearing an established worm burden. Revista da Sociedade Brasileira de Medicina Tropical 24:217-221, out-dez, 1991

occurs more frequently than previously suspected.

\section{MATERIAL AND METHODS}

Ascaris collected from nine autopsy and from one surgical case were rinsed in tap water and stored in $10 \%$ formalin. The worms were grouped by gender and individually weighed and measured. When necessary a dissecting microscope was used for identification of males and females. The age and sex distribution of the ten children are in Table 1.

For each case the mean, the median and the standard deviation were calculated for the weight and length of worms. The " $z$ " scores were calculated to indicate the largest worm which would be considered a member of the same population with $99 \%$ confidence level $(p<0.01)$. All the worms with " $\mathrm{z}$ " scores higher than 2.33 were grouped and compared with the others with " $z$ " scores lower than 2.33. For comparison of the means the Student " $t$ " test was used.

\section{RESULTS}

The results are shown in Tables 1,2 and 3 in Figures 1 and 2. Analysis of the distribution of the weight and length (Tables 1 and 2) identified seven cases in which the mean and the median were similar, and in which the standard deviation and the coefficient of variation (Table 3) indicated a relatively small dispersion of values around the mean. However in four of these seven cases, one or two worms were found with " $z$ " scores above 2.33 (Table 3). The Figure 1 shows clearly the unimodal distribution of worm's size in those cases.

In case 10, as showed in Tables 1,2 and 3, the standard deviation and coefficient of variation were great but there were not worms with " $z$ " scores above 2.33. However the bimodal distribution of worm's size (Figure 2) showed clearly the existance of two distinct populations. The student's " $t$ " test showed a significant difference between the means of worm size of these two distinct populations.

Table 1 - Weight $(g)$ of worms colected from children with ascariasis.

\begin{tabular}{|c|c|c|c|c|c|c|c|c|}
\hline \multirow{2}{*}{$\frac{\text { Case }}{1}$} & \multirow{2}{*}{$\frac{\text { Age }}{6}$} & \multirow{2}{*}{$\frac{\text { Sex }}{\mathrm{m}}$} & \multicolumn{2}{|c|}{$\mathrm{N}$ of worms } & \multirow{2}{*}{$\begin{array}{l}\text { Mean } \\
0.55 \\
1.34\end{array}$} & \multirow{2}{*}{$\begin{array}{c}\mathrm{s} \\
0.19 \\
0.53\end{array}$} & \multirow{2}{*}{$\begin{array}{c}\text { Median } \\
\begin{array}{c}0.54 \\
1.35\end{array}\end{array}$} & \multirow{2}{*}{$\begin{array}{c}\text { Range } \\
0.19-1.02 \\
0.23-2.93\end{array}$} \\
\hline & & & $\begin{array}{c}\mathbf{m} \\
\mathbf{f}\end{array}$ & $\begin{array}{l}51 \\
90\end{array}$ & & & & \\
\hline 2 & 3 & f & $\begin{array}{c}\mathbf{m} \\
\mathbf{f}\end{array}$ & $\begin{array}{l}32 \\
41\end{array}$ & $\begin{array}{l}0.65 \\
1.71\end{array}$ & $\begin{array}{l}0.18 \\
0.32\end{array}$ & $\begin{array}{l}0.64 \\
1.78\end{array}$ & $\begin{array}{l}0.35-1.48 \\
0.92-2.56\end{array}$ \\
\hline 3 & 5 & f & $\underset{\mathrm{f}}{\mathrm{m}}$ & $\begin{array}{l}82 \\
65\end{array}$ & $\begin{array}{l}0.90 \\
2.76\end{array}$ & $\begin{array}{l}0.14 \\
0.52\end{array}$ & $\begin{array}{l}0.90 \\
2.80\end{array}$ & $\begin{array}{l}0.76-1.21 \\
1.50-4.50\end{array}$ \\
\hline 4 & 2 & f & $\underset{\mathbf{f}}{\mathbf{m}}$ & $\begin{array}{l}22 \\
22\end{array}$ & $\begin{array}{l}0.97 \\
2.37\end{array}$ & $\begin{array}{l}0.17 \\
0.42\end{array}$ & $\begin{array}{l}0.99 \\
2.53\end{array}$ & $\begin{array}{l}0.70-1.31 \\
0.58-3.22\end{array}$ \\
\hline 5 & 2 & f & $\underset{f}{m}$ & $\begin{array}{l}13 \\
14\end{array}$ & $\begin{array}{l}0.35 \\
0.74\end{array}$ & $\begin{array}{l}0.11 \\
0.53\end{array}$ & $\begin{array}{l}0.35 \\
0.71\end{array}$ & $\begin{array}{l}0.20-0.66 \\
0.25-2.15\end{array}$ \\
\hline 6 & 7 & f & $\begin{array}{c}\mathbf{m} \\
\mathbf{f}\end{array}$ & $\begin{array}{l}4 \\
4\end{array}$ & $\begin{array}{l}1.20 \\
3.73\end{array}$ & $\begin{array}{l}0.14 \\
0.09\end{array}$ & $\begin{array}{l}1.12 \\
3.73\end{array}$ & $\begin{array}{l}1.12-1.42 \\
3.65-3.82\end{array}$ \\
\hline 7 & 11 & $\mathrm{~m}$ & $\underset{f}{m}$ & $\begin{array}{l}19 \\
13\end{array}$ & $\begin{array}{l}1.57 \\
4.21\end{array}$ & $\begin{array}{l}0.23 \\
0.35\end{array}$ & $\begin{array}{l}1.55 \\
4.12\end{array}$ & $\begin{array}{r}1.25-2.12 \\
3.42-4.88\end{array}$ \\
\hline 8 & 4 & $\mathbf{m}$ & $\begin{array}{c}\mathbf{m} \\
\mathbf{f}\end{array}$ & $\begin{array}{l}126 \\
229\end{array}$ & $\begin{array}{l}0.27 \\
0.47\end{array}$ & $\begin{array}{l}0.23 \\
0.74\end{array}$ & $\begin{array}{l}0.20 \\
0.30\end{array}$ & $\begin{array}{l}0.05-1.33 \\
0.07-5.34\end{array}$ \\
\hline 9 & 2 & $\mathrm{f}$ & $\underset{f}{m}$ & $\begin{array}{l}11 \\
32\end{array}$ & $\begin{array}{l}0.13 \\
0.29\end{array}$ & $\begin{array}{l}0.12 \\
0.44\end{array}$ & $\begin{array}{l}0.08 \\
0.07\end{array}$ & $\begin{array}{l}0.01-0.46 \\
0.01-1.55\end{array}$ \\
\hline 10 & 5 & $\mathbf{m}$ & $\begin{array}{c}\mathbf{m} \\
\mathbf{f}\end{array}$ & $\begin{array}{l}24 \\
32\end{array}$ & $\begin{array}{l}0.65 \\
2.73\end{array}$ & $\begin{array}{l}0.54 \\
1.62\end{array}$ & $\begin{array}{l}0.37 \\
3.47\end{array}$ & $\begin{array}{l}0.17-1.72 \\
0.32-5.28\end{array}$ \\
\hline
\end{tabular}

$m=$ male $f=$ female 
Pereira FEL, Sampaio AP, Musso C, Castelo JS. Ascaris lumbricoides. reinfection in children bearing an established worm burden. Revista da Sociedade Brasileira de Medicina Tropical 24:217-221, out-dez, 1991

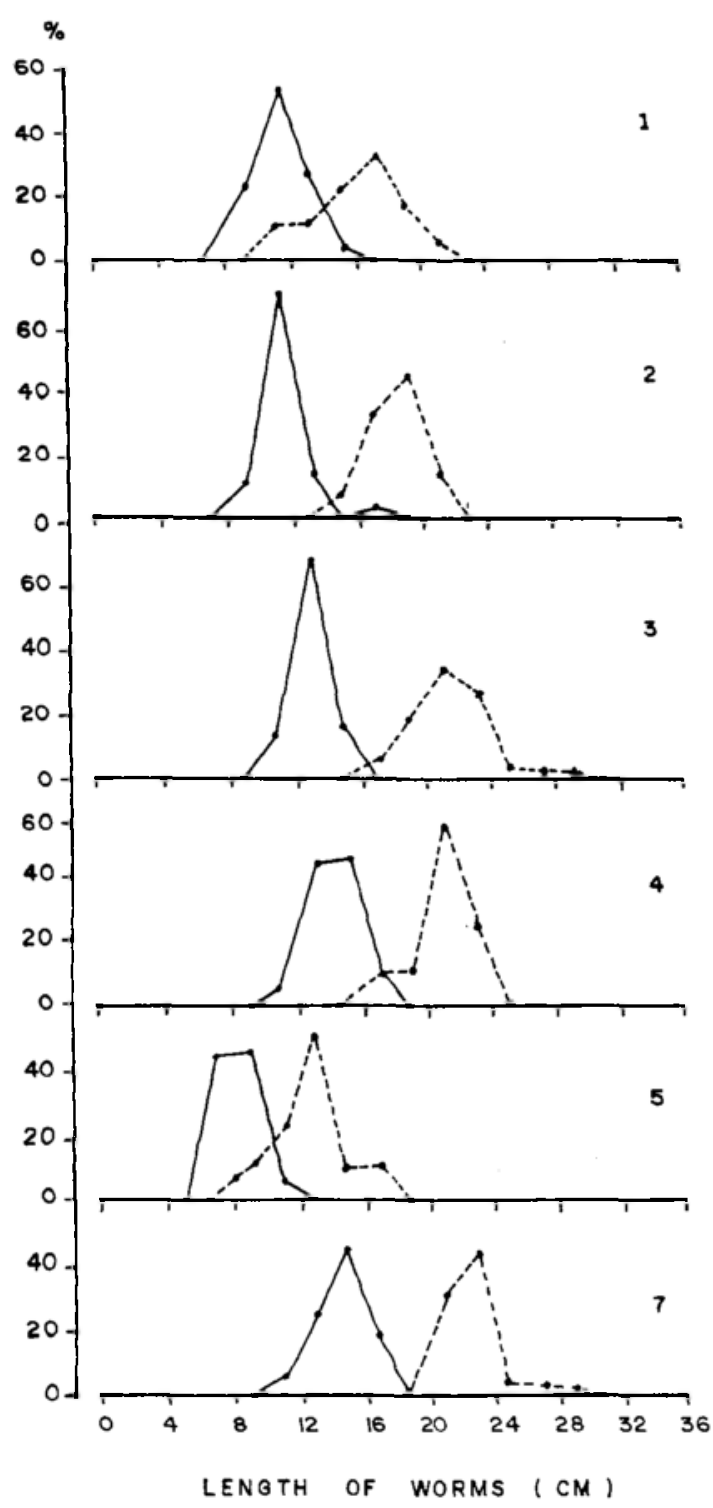

Figure 1: Frequency distribution of worms'size in six cases of acariasis in children in which the length of worms showed little variation with an unimodal distribution. The numbers at right indicate each case as in Tables 1,2 and 3.

(male worms female worms - -$)$
In cases 8 and 9 the worm analysis revealed different values for the mean and the median, and the standard deviation was great, with values near or above the values for the mean. In these two cases 17 and 8 worms respectively were identified with " $z$ " scores above 2.33, and thus could be considered as distinct populations at a confidence level of $99 \%$ $(p<0.01)$. Comparison of the means of weigths and lengths of worms with " $z$ " scores greater than 2.33 with the means observed for the worms with " $z$ " scores less than 2.33 revealed significant differences.

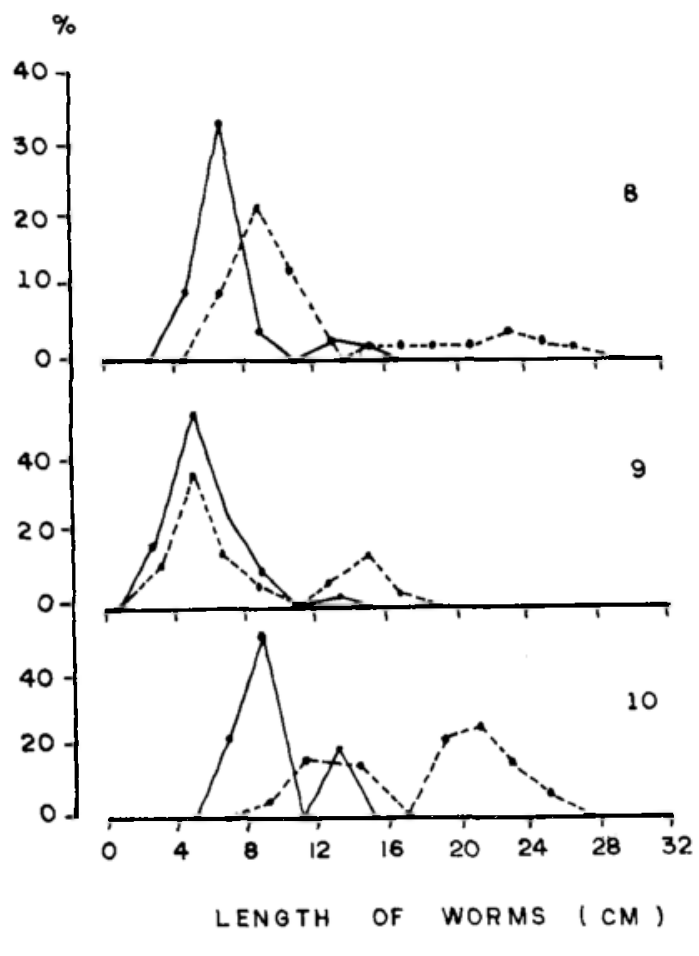

Figure 2: Frequency distribution of worms'size in three cases of acariasis in children in which the length of worms showed great variation with a bimodal distribution. The numbers at right indicate each case as in Tables 1,2 and 3.

(male worms female worms -...-.-) 
Pereira FEL, Sampaio AP, Musso C, Castelo JS. Ascaris lumbricoides: reinfection in children bearing an established worm burden. Revista da Sociedade Brasileira de Medicina Tropical 24:217-221, out-dez, 1991

Table 2 - Size of worms (cm) collected from children with ascariasis.

\begin{tabular}{|c|c|c|c|c|c|c|}
\hline \multirow{2}{*}{$\frac{\text { Case }}{1}$} & \multicolumn{2}{|c|}{$\mathrm{N}$ of worms } & \multirow{2}{*}{$\begin{array}{c}\text { Mean } \\
\begin{array}{l}11.6 \\
16.8\end{array}\end{array}$} & \multirow{2}{*}{ 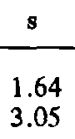 } & \multirow{2}{*}{$\begin{array}{c}\text { Median } \\
\begin{array}{l}12.0 \\
17.5\end{array}\end{array}$} & \multirow{2}{*}{$\begin{array}{c}\text { Range } \\
7.5-15.5 \\
7.0-22.5\end{array}$} \\
\hline & $\underset{\mathbf{f}}{\mathrm{m}}$ & $\begin{array}{l}51 \\
90\end{array}$ & & & & \\
\hline 2 & $\begin{array}{c}\mathrm{m} \\
\mathrm{f}\end{array}$ & $\begin{array}{l}32 \\
41\end{array}$ & $\begin{array}{l}12.0 \\
18.9\end{array}$ & $\begin{array}{l}1.30 \\
1.59\end{array}$ & $\begin{array}{l}12.0 \\
19.0\end{array}$ & $\begin{array}{r}9.5-17.0 \\
15.0-22.0\end{array}$ \\
\hline 3 & $\begin{array}{c}\mathbf{m} \\
\mathbf{f}\end{array}$ & $\begin{array}{l}82 \\
65\end{array}$ & $\begin{array}{l}13.6 \\
21.9\end{array}$ & $\begin{array}{l}1.07 \\
2.07\end{array}$ & $\begin{array}{l}14.0 \\
22.0\end{array}$ & $\begin{array}{l}12.0-16.5 \\
18.0-29.5\end{array}$ \\
\hline 4 & $\underset{\mathrm{f}}{\mathrm{f}}$ & $\begin{array}{l}22 \\
22\end{array}$ & $\begin{array}{l}14.8 \\
21.8\end{array}$ & $\begin{array}{l}1.38 \\
1.77\end{array}$ & $\begin{array}{l}14.5 \\
21.7\end{array}$ & $\begin{array}{l}12.5-17.2 \\
17.0-24.0\end{array}$ \\
\hline 5 & $\stackrel{\mathrm{m}}{\mathrm{f}}$ & $\begin{array}{l}13 \\
14\end{array}$ & $\begin{array}{r}8.9 \\
12.5\end{array}$ & $\begin{array}{l}1.04 \\
2.77\end{array}$ & $\begin{array}{r}8.8 \\
12.8\end{array}$ & $\begin{array}{l}7.0-10.5 \\
8.3-18.5\end{array}$ \\
\hline 6 & $\underset{\mathbf{f}}{\mathrm{m}}$ & $\begin{array}{l}4 \\
4\end{array}$ & $\begin{array}{l}14.3 \\
24.5\end{array}$ & $\begin{array}{l}2.42 \\
1.91\end{array}$ & $\begin{array}{l}16.2 \\
23.0\end{array}$ & $\begin{array}{l}13.0-17.5 \\
23.0-27.0\end{array}$ \\
\hline 7 & $\underset{f}{m}$ & $\begin{array}{l}19 \\
13\end{array}$ & $\begin{array}{l}15.5 \\
24.0\end{array}$ & $\begin{array}{l}1.48 \\
2.08\end{array}$ & $\begin{array}{l}15.5 \\
24.0\end{array}$ & $\begin{array}{l}12.5-18.3 \\
21.9-29.0\end{array}$ \\
\hline 8 & $\stackrel{\mathrm{m}}{\mathrm{f}}$ & $\begin{array}{l}126 \\
229\end{array}$ & $\begin{array}{r}7.9 \\
10.7\end{array}$ & $\begin{array}{l}2.10 \\
3.03\end{array}$ & $\begin{array}{r}8.0 \\
10.5\end{array}$ & $\begin{array}{l}5.5-15.5 \\
6.0-28.0\end{array}$ \\
\hline 9 & $\underset{f}{m}$ & $\begin{array}{l}11 \\
32\end{array}$ & $\begin{array}{l}6.5 \\
7.7\end{array}$ & $\begin{array}{l}2.06 \\
4.61\end{array}$ & $\begin{array}{l}6.2 \\
6.7\end{array}$ & $\begin{array}{l}3.5-10.5 \\
3.0-18.5\end{array}$ \\
\hline 10 & $\begin{array}{c}\mathrm{m} \\
\mathrm{f}\end{array}$ & $\begin{array}{l}24 \\
32\end{array}$ & $\begin{array}{l}10.5 \\
19.5\end{array}$ & $\begin{array}{l}2.66 \\
4.36\end{array}$ & $\begin{array}{r}9.5 \\
20.0\end{array}$ & $\begin{array}{r}7.5-15.5 \\
10.6-26.0\end{array}$ \\
\hline
\end{tabular}

$\mathrm{m}=$ male $\mathrm{f}=$ female

\section{DISCUSION}

Our results showed that in seven of ten cases of ascariasis in children there was a regular distribution of worm's size. In these cases the variation in size observed was similar to that reported by Jung' ${ }^{2}$ and by Takata et $\mathrm{al}^{6}$ although these authors provided the range of values and not the standard deviation. Thus in six cases, our observations are in agreement with the concept of a single brood infection in human ascariasis. Althoug we observed in four cases at least one worm with " $\mathrm{z}$ " score greater than 2.33, we believe that these worms are the remnant of a previous infection which declined through senescenceor, perhaps, in the face of a new infection. In these four cases it is possible that the apparent reinfection occurred at the end of the life-span of a pre-existing worm burden.

In two cases (cases 8 and 9) the great variation in worm's size indicated by the high value of coefficient of variation and the great number of worms with " $z$ " scores above 2.33 show clearly the coexistence of two distinct worm's populations: one composed of numerous small imature worms and the other of large mature worms in case 8 and composed of two populations of imature worms in case 9.

In case 10 the standard deviation and coefficient of variation were great but there were not worms with " $z$ " scores above 2.33: the existance of two distinct populations was clearly demonstrated by the bimodal distribution of the values for the weigth and the length. In this case the two populations were composed of imature and mature worms.

Our observations are in agreement with those of Baird et al' in that, in the cases 8,9 and 10 the patients appear to have acquired a reinfection with Ascaris while hosting a light but significant worm burden. While the mechanisms of reinfection in these cases is unknown. Baird et $a^{1}$ invoked undernutrion as a possible predisposing factor in their single case, and we found evidence of 
Table 3 - Coefficient of variation for length and weigth of worms and number of worms and number or worms with " $z$ " scores above 2.33 in ten cases of ascariasis in children

\begin{tabular}{|c|c|c|c|c|c|}
\hline \multirow[b]{2}{*}{ Case } & \multicolumn{3}{|c|}{ Length } & \multicolumn{2}{|c|}{ Weight } \\
\hline & $\mathrm{CV}(\%)$ & & $z>2.33$ & $\mathrm{CV}(\%)$ & $z>2.33$ \\
\hline 1 & $\underset{\mathbf{f}}{\mathbf{m}}$ & $\begin{array}{l}14 \\
18\end{array}$ & $\begin{array}{l}0 \\
1\end{array}$ & $\begin{array}{l}36 \\
40\end{array}$ & $\begin{array}{l}0 \\
1\end{array}$ \\
\hline 2 & $\underset{\mathrm{f}}{\mathbf{m}}$ & $\begin{array}{r}10 \\
8\end{array}$ & $\begin{array}{l}0 \\
0\end{array}$ & $\begin{array}{l}28 \\
19\end{array}$ & $\begin{array}{l}1 \\
1\end{array}$ \\
\hline 3 & $\begin{array}{c}\mathrm{m} \\
\mathrm{f}\end{array}$ & $\begin{array}{l}7 \\
9\end{array}$ & $\begin{array}{l}1 \\
0\end{array}$ & $\begin{array}{l}16 \\
19\end{array}$ & $\begin{array}{l}0 \\
1\end{array}$ \\
\hline 4 & $\mathbf{m}$ & $\begin{array}{l}9 \\
8\end{array}$ & $\begin{array}{l}0 \\
0\end{array}$ & $\begin{array}{l}19 \\
18\end{array}$ & $\begin{array}{l}0 \\
0\end{array}$ \\
\hline 5 & $\begin{array}{c}\mathbf{m} \\
\mathbf{f}\end{array}$ & $\begin{array}{l}11 \\
22\end{array}$ & $\begin{array}{l}0 \\
0\end{array}$ & $\begin{array}{l}33 \\
71\end{array}$ & 1 \\
\hline 6 & $\underset{f}{m}$ & $\begin{array}{r}16 \\
7\end{array}$ & $\begin{array}{l}0 \\
0\end{array}$ & $\begin{array}{r}11 \\
3\end{array}$ & $\begin{array}{l}0 \\
0\end{array}$ \\
\hline 7 & $\underset{f}{m}$ & $\begin{array}{l}9 \\
9\end{array}$ & $\begin{array}{l}0 \\
0\end{array}$ & $\begin{array}{r}14 \\
8\end{array}$ & $\begin{array}{l}0 \\
0\end{array}$ \\
\hline 8 & $\underset{\mathbf{f}}{\mathrm{m}}$ & $\begin{array}{l}26 \\
31\end{array}$ & $\begin{array}{l}7 \\
9\end{array}$ & $\begin{array}{r}90 \\
158\end{array}$ & $\begin{array}{r}7 \\
10\end{array}$ \\
\hline 9 & $\underset{\mathbf{f}}{\mathrm{f}}$ & $\begin{array}{l}31 \\
59\end{array}$ & $\frac{1}{7}$ & $\begin{array}{r}91 \\
147\end{array}$ & $\frac{1}{7}$ \\
\hline 10 & $\underset{f}{m}$ & $\begin{array}{l}18 \\
22\end{array}$ & $\begin{array}{l}0 \\
0\end{array}$ & $\begin{array}{l}83 \\
56\end{array}$ & $\begin{array}{l}0 \\
0\end{array}$ \\
\hline
\end{tabular}

$\overline{C V}=$ coefficient of variation

undernutrion in two of three children with reinfection. It remains possible that other factors are responsible for this phenomenon. In conclusion our results demonstrate that reinfection in ascariasis is not rare, and that the resistance observed with a pre-existing worm burden is not invariable.

\section{RESUMO}

Para tentar esclarecer a existência de reinfecção em crianças portadoras de ascaridiase já estabelecida, foram avaliados o peso e o comprimento dos vermes colhidos em 10 casos de ascaridiase, em nove dos quais a carga parasitária foi maior do que 27 vermes. Em sete casos o peso e o comprimento dos vermes apresentaram pouca variação, com distribuição unimodal dos valores, sugerindo assim pertencerem todos a uma mesma população originada de uma única infecção ou de infecções repetidas com intervalos muito curtos. Em três casos, o peso e o comprimento dos vermes mostraram grande variação, indicada pelos valores diferentes para as médias e as medianas e dos altos valores dos desvios padrão e dos coeficientes de variação. Nesses casos, a distribuição dos valores para o comprimento e para o peso foi bimodal, sugerindo a coexistência de duas populações diferentes de vermes: uma, menos numerosa, composta de vermes já maduros e outra, mais numerosa composta de vermes imaturos em dois casos e duas populações de vermes imaturos em um caso. A presença de populações distintas de vermes, com diferentes graus de maturidade, indica que a população mais imatura foi adquirida quando a populaçđo mais desenvolvida já estava estabelecida no intestino. Esses resultados demonstram que a reinfecção com Ascaris em crianças portadoras de ascaridíase estabelecida não é rara e que a resistência induzida por uma infecção pré-existente não é um fato invariável.

Palavras-chaves: Ascaris lumbricoides. Ascariase.

\section{REFERENCES}

1. Baird JK, Mistrey M, Pimsler M, Connor DH. Fatal human ascariasis following secondary massive infection. The American Journal of Tropical Medicine and Hygiene 35:314-318, 1988.

2. Jung RC. The predominance of single brood infection in human ascariasis. Journal of Parasitology 48:405-407, 1984.

3. Otto GF. Ascaris lumbricoides: treatment and loss of worms and reinfection. Journal of American Medical Association 95:194-195, 1930.

4. Sadun EH. Resistance induced in chickens by infection with the nematode Ascaridia galli. The American Journal of Hygiene 47:282-289, 1948.

5. Sprent JFA, Chen HH. Immunological studies in mice infected with larvae of Ascaris lumbricoides. In: Criteria of immunity and immunizing effects of worm tissues. Joumal of Infectious Diseases 84:111-124, 1949.

6. Takata I. Experimental infection with Ascaris of pig and man. Kitasato Archives of Experimental Medicine 23:49-59, 1951. 